\title{
Improved Design of a 25 MW Gas Turbine Plant Using Combined Cycle Application
}

\author{
Barinaadaa Thaddeus Lebele-Alawa, Anthony Kpegele Le-ol \\ Department of Mechanical Engineering, Rivers State University of Science and Technology, Port Harcourt, \\ Nigeria \\ Email: lebele-alawa.thaddeus@ust.edu.ng, le-ol.anthony@ust.edu.ng
}

Received 5 June 2015; accepted 18 July 2015; published 21 July 2015

Copyright (C) 2015 by authors and Scientific Research Publishing Inc.

This work is licensed under the Creative Commons Attribution International License (CC BY). http://creativecommons.org/licenses/by/4.0/

(c) (i) Open Access

\section{Abstract}

This paper presents the improved design of a $25 \mathrm{MW}$ gas turbine power plant at Omoku in the Niger Delta area of Nigeria, using combined cycle application. It entails retrofitting a steam bottoming plant to the existing $25 \mathrm{MW}$ gas turbine plant by incorporating a heat recovery steam generator. The focus is to improve performance as well as reduction in total emission to the environment. Direct data collection was performed from the HMI monitoring screen, log books and manufacturer's manual. Employing the application of MATLAB, the thermodynamics equations were modeled and appropriate parameters of the various components of the steam turbine power plant were determined. The results show that the combined cycle system had a total power output of $37.9 \mathrm{MW}$, made up of $25.0 \mathrm{MW}$ from the gas turbine power plant and 12.9 MW (an increase of about $51 \%$ ) from the steam turbine plant, having an HRSG, condenser and feed pump capacities of 42.46 MW, 29.61 MW and 1.76 MW respectively. The condenser cooling water parameters include a mass flow of $1180.42 \mathrm{~kg} / \mathrm{s}$, inlet and outlet temperatures of $29.8^{\circ} \mathrm{C}$ and $35.8^{\circ} \mathrm{C}$ respectively. The cycle efficiency of the dry mode gas turbine was $26.6 \%$ whereas, after modification, the combined cycle power plant overall efficiency is $\mathbf{4 8 . 8 \%}$ (about $\mathbf{8 4 \%}$ increases). Hence, SIEMENS steam turbine product of MODEL: SST-150 was recommended as the steam bottoming plant. Also the work reveals that a heat flow of about $42.46 \mathrm{MW}$ which was otherwise being wasted in the exhaust gas of the $25 \mathrm{MW}$ gas turbine power plant could be converted to $12.9 \mathrm{MW}$ of electric power, thus reducing the total emission to the environment.

\section{Keywords}

Gas Turbine, Steam Turbine, HRSG, Combined Cycle, Power Output, Overall Efficiency, Condenser Cooling Water 


\section{Introduction}

Energy is a basic requirement for human existence, and thus a driving force of civilization as almost all of our everyday activities and productive processes involve energy in one form or another [1]. The economic development and living standard of any society is a function of the availability and accessibility of electrical power to her. Therefore, the acknowledgement of the importance of increasing access to commercial electricity is fundamental for the future and sustainable development of any society [2].

The increased world population and the quest to improve living conditions as well as global economic growth have resulted in a continuous increase in energy demand [3]. Accommodating the projected increase in energy demand must be approached with caution as it is now generally accepted that human activities such as burning of fossil fuels involved in energy systems are the main sources of acid rain and greenhouse gases which are the major contributor to global climatic change [4]. Yadav [5] in his work, observed that one of the greatest challenges facing humanity during the twenty-first century is that of giving everyone on the planet access to safe, clean and sustainable energy supplies.

Anheden [6] did a study on the analysis of gas turbine systems for sustainable energy conversion and suggested that one way to provide the energy service demand by the growing populations, and yet reduce the $\mathrm{CO}_{2}$ emissions, is to increase the energy conversion efficiency of existing and future energy conversion processes by various technological advancements. Nkoi et al. [7] in their work on investigations encompassing comparative assessment of gas turbine (GT) cycle optional also observed that a modified gas turbine cycle configurations incorporating unconventional components such as engine cycle with low pressure compressor (LPC) zero-staged, recuperated engine cycle, and intercooled/recuperated (ICR) engine cycle exhibited better performances in terms of thermal efficiency and specific fuel consumption than the traditional simple cycle engine. A study on power increase and economical results of different efficiency improvement methods has revealed that fogging and evaporative method are the most effective methods of efficiency improvement in Khoramshahr power plant [8].

Severally, there have often been suggestions from literatures of the combination of two or more thermal cycles within a single power plant with the intention of increasing efficiency over that of single cycles. In a study on the performance of combined gas turbine-steam cycle for power generation, it was noted that thermal processes can be combined in this way whether they operate with the same or with differing working media. The study concluded that a combination of cycles with different working media as in combined cycle is more interesting because their advantage can complement one another [9]. Korobitsyn [10] in his analysis of cogeneration, combined and integrated cycles observed that improved efficiency can be achieved by modifications to the original simple cycle to recover heat from the turbine exhaust for generation of steam in a steam turbine bottoming cycle as found in combined cycle.

A combined cycle power plant (CCPP) is a power plant where electricity production is done from the combination of both gas and steam turbines. Previous work has been done on rotor-blades' profile influence on a gas compressor effectiveness. The study stated that in the gas turbine, atmospheric air is drawn in through an intake duct and compressed to a high pressure in the compressor consisting of a cascade of several stages of blades located on a single axle in radial form [11] [12]. The high pressure air is delivered to the combustor where fuel is sprayed and the high pressure and temperature product of combustion impinges on the turbine blades which rotates the shaft that drives an electrical generator to produce electricity and the exhaust gas energy from the gas turbine is used to generate steam in a heat recovery steam generator (HRSG) which then produces more electricity from a steam turbine. There is a great potential for increased power output and efficiency, as well as reduction of emitted pollutants to the environment, in energy converting devices by recovering waste heat to a greater extent. It was observed that the development of combined cycle power plant is the most efficient and effective effort in this direction. This is gaining increasing acceptance as an alternative to conventional gas or steam cycle due to high thermal efficiency of about $60 \%$ utilizing natural gas as fuel [5].

Ragland et al. [13] did a study on combined cycle heat recovery optimization and observed that combustion turbine performance has the primary impact on combined cycle plant efficiency and the next most important piece of equipment that impacts efficiency is the heat recovery steam generator (HRSG). The study continued that in the design of CCPP, the HRSG parameters to optimize include steam pressure, temperature, flows, pinch points, approach temperatures and HRSG exit gas temperature. The HRSG is a heat exchanger comprising three components namely the economizer, the evaporator, and the superheater and can be designed with typical configurations of single-pressure or multiple-pressure levels, with or without supplementary firing. In a study on the 
optimization of Maputo power plant, it was observed that the most important design parameter of a steam turbine is the steam data which include the mass flow and the steam turbine input pressure and temperature, as well as the condenser pressure [14].

To effectively harness heat from the HRSG so as to have a higher combined cycle thermal efficiency, the stack temperature should be reduced as much as possible but not below the acid dew point of the flue gas to avoid levels of condensation. Acid dew point of exhaust gas is within the range of $104^{\circ} \mathrm{C}-160^{\circ} \mathrm{C}$ [15]. In a study on combined cycle gas and steam turbine power plants, the typical steam turbine outlet pressure in condensing mode ranges from 0.03 to 0.25 bar [16] while Aref [17] in his work on development of framework for thermo-economic optimization of simple and combined gas turbine cycles indicated that pinch point is usually between $8^{\circ} \mathrm{C}$ and $15^{\circ} \mathrm{C}$ and approach temperature is in the range $8^{\circ} \mathrm{C}-12^{\circ} \mathrm{C}$.

This paper considers an improved design of the Omoku gas turbine power plant using combined cycle application, with the aim of increasing its performance (power output and efficiency) as well as reducing the total emission to the environment. It analyzes a suitable HRSG capable of producing steam at an effective pressure which will utilize the exhaust gas from the gas turbine to power the steam turbine.

The Omoku gas turbine is located in the Niger Delta area of Nigeria. It has six (6) units, each consisting of a gas turbine for electricity generation of $25 \mathrm{MW}$ and exhaust gas temperature of $487^{\circ} \mathrm{C}$. The manufacturer of the gas turbine system is General Electric (GE) and it is an MS 5001 (GE Frame 5), single shaft model having a double bus single breaker; $3 \times 80$ MVA transformer and a $33 \mathrm{kV}$ to $132 \mathrm{kV}$ line switchyard system which is capable of evacuating $200 \mathrm{MW}$ of power [18].

It is observed that the hot exhaust gas from the Omoku gas plant is vented to the atmosphere, as common to all conventional open cycle gas turbines; hence, considerable amount of heat energy goes as waste with the exhaust of the gas turbine, thus, contributing to environmental pollution. Rather than flaring the hot exhaust gas from this Brayton cycle plant, this heat can be utilized for other useful purposes using heat recovery steam generator (HRSG). This reason prompted the need for the improved design of the Omoku gas turbine power plant to a combined-cycle system such that the otherwise wasted heat from the hot exhaust gas is captured and channeled into the HRSG and used to generate steam to drive another generator (steam generator) to produce more electricity, thus improving the performance (increased total output and efficiency) with less environmental pollution compared to the single cycle turbine plant. Hence, a combined cycle power plant (CCPP) usually consists of a Gas turbine plant, a HRSG and a Steam turbine plant. The gas turbine plant operating on Brayton cycle and the steam turbine plant operating on rankine cycle are often called topping and bottoming cycles respectively [19]. As common to all conventional CCPP, this modification requires a source of cooling water to be utilized in the condensing unit of the proposed steam turbine system. However, it is interesting to know that there is a flowing river close to the Omoku gas plant which enhances the availability of water source for this purpose, justifying the feasibility of the study.

\section{Materials and Methods}

The research methodologies adopted are as follows:

1) Data collection of the Omoku Gas turbine power plant (GE FRAME 5-MS 5001 PA—Single Shaft) from direct observation from the monitoring screen of the human machine interface (HMI), log books and manufacturer's manuals.

2) Assessment of the current plant condition.

3) MATLAB software was used to model the standard thermodynamic relations and equations for the analysis of the turbo-machinery components of the gas turbine to determine the heat energy rejected in the exhaust gas of the existing plant so as to ascertain the corresponding power that can match with the exhaust gas temperature (EGT).

4) Determination of a suitable capacity (sizing) of a heat recovery steam generator (HRSG).

5) From the relevant design calculations, the capacities of other components of the proposed steam turbine system were determined. They include the turbine, condenser, boiler and feed pump. Hence the steam turbine components that will match with the existing gas turbine were selected.

6) The power output and efficiency of the steam turbine, hence, power output and efficiency of the combined cycle gas turbine plant were determined.

Table 1 displays the necessary data required for the performance analysis of the power plant which equally 
serve as the input data for the design/conversion to a combined cycle. Also, the ambient conditions of the physical environment of the plant vicinity were noted $\eta_{t h_{g T}}$.

\subsection{Analytical Model of the Combined Gas and Steam}

\subsubsection{Performance of a Theoretical Heat Balance on HRSG}

This will give us the relationship between the tube side and shell side processes. It is also important that tube side components which will make up the HRSG unit be decided. Even though these components may include other heat exchange services, at this time we will only consider the three primary coil types namely; Economizer, Evaporator and Super heater as shown in Figure 1.

From Figure 1, the steam temperature increases form point 4 to 1 . Process 4 - 5 occur in the economizer; 5 - 6 occur in the evaporator, and 6 - 1 is superheating.

The exhaust gas is cooled from point $T_{d}$ of the gas turbine to a temperature of $T_{a}$ well above its acid dew point temperature. The pinch points are $\mathrm{x}-5$ and $\mathrm{d}-1$. A pinch and approach temperature of $10^{\circ} \mathrm{C}$ is used in order to

Table 1. Average operating data for Omoku gas turbine plant.

\begin{tabular}{|c|c|c|c|c|}
\hline Component & Parameter & Symbol & Unit & Value \\
\hline \multirow{5}{*}{ Turbo compressor } & Inlet temperature & $T_{1}$ & ${ }^{\circ} \mathrm{C}$ & 30.4 \\
\hline & Outlet temperature & $T_{2}$ & ${ }^{\circ} \mathrm{C}$ & 367 \\
\hline & Inlet pressure & $P_{1}$ & bar & 1.013 \\
\hline & Outlet pressure & $P_{2}$ & bar & 10 \\
\hline & Mass flow rate (Air) & $\dot{m}_{a}$ & $\mathrm{~kg} / \mathrm{s}$ & 122.9 \\
\hline \multirow{2}{*}{ Combustion chamber } & Fuel consumption (flow rate) & $\dot{m}_{f}$ & $\mathrm{~kg} / \mathrm{s}$ & 1.2 \\
\hline & Inlet temperature & $T_{3}$ & ${ }^{\circ} \mathrm{C}$ & 959 \\
\hline \multirow{2}{*}{ Gas turbine } & Outlet temperature & $T_{4}$ & ${ }^{\circ} \mathrm{C}$ & 487 \\
\hline & Exhaust gas flow (flow rate of gas) & $\dot{m}_{e g}$ & $\mathrm{~kg} / \mathrm{s}$ & 124.1 \\
\hline \multirow{2}{*}{ Other data } & GT Thermal efficiency & $\eta_{t t_{g} T}$ & $\%$ & 26.6 \\
\hline & GT Power output & $P_{g T}$ & MW & 25 \\
\hline
\end{tabular}

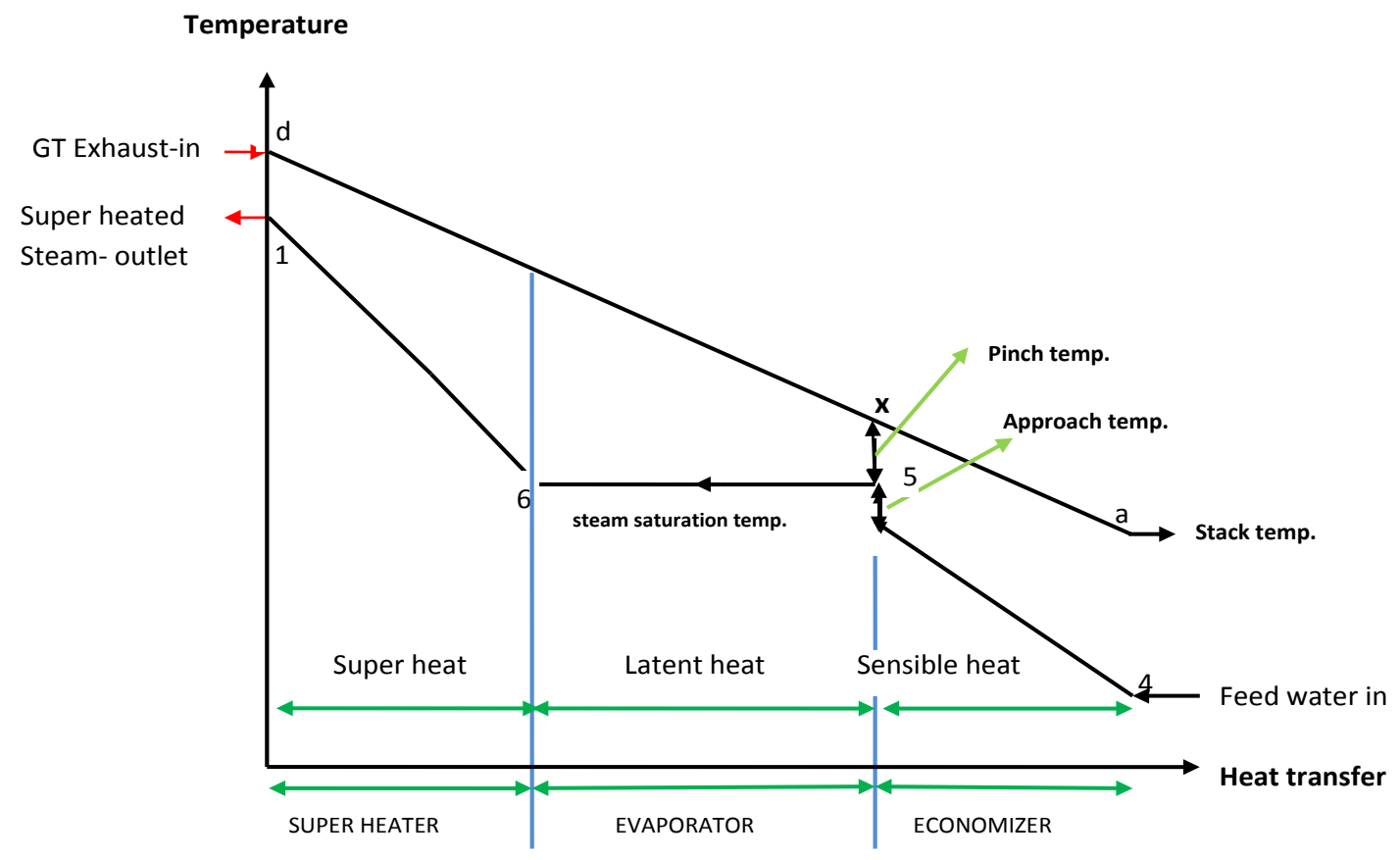

Figure 1. Variation of heat flow with temperature between exhaust gas and HRSG. 
minimize heat loss between exhaust gas and steam and at the same time ensure heat transfer for maximum power output.

Applying the heat balance equations between the gas turbine exhaust and HRSG as given below:

$$
\begin{gathered}
\dot{m}_{s}\left(h_{1}-h_{4}\right)=\dot{m}_{e g} c_{p e g}\left(T_{d}-T_{a}\right) \\
\dot{m}_{s}\left(h_{5}-h_{4}\right)=\dot{m}_{e g} c_{p e g}\left(T_{x}-T_{a}\right)
\end{gathered}
$$

Heat rejected by exhaust gas is given by

$$
\dot{Q}_{e g}=\dot{m}_{e g} c_{p e g}\left(T_{d}-T_{a}\right)
$$

where;

$\dot{m}_{s}=$ Mass flow rate of steam in $\mathrm{kg} / \mathrm{s}$

$\dot{m}_{e g}=$ Mass flow rate of exhaust gas in $\mathrm{kg} / \mathrm{s}$

$T_{a}=$ Cooling temperature of exhaust gas (HRSG stack temperature)

$T_{x}=$ Temperature of exhaust gas at pinch point

$T_{d}=$ Temperature of exhaust gas at gas turbine outlet

$m_{e q}=$ Specific heat of exhaust gas

The capacities of the various components of the HRSG are thus estimated as follows:

\section{Economizer:}

$$
Q_{e c}=Q_{e g_{e c}} \times \dot{m}_{e g}=\left(h_{5}-h_{4}\right) \dot{m}_{s}
$$

Evaporator:

$$
Q_{e v}=Q_{e g_{e v}} \times \dot{m}_{e g}=\left(h_{6}-h_{5}\right) \dot{m}_{s}
$$

Superheater:

$$
Q_{s h}=Q_{e g_{s h}} \times \dot{m}_{e g}=\left(h_{1}-h_{6}\right) \dot{m}_{s}
$$

HRSG capacity:

$$
Q_{H R S G}=Q_{e c}+Q_{e v}+Q_{s h}
$$

Heat Loss

$$
H_{L}=\dot{Q}_{e g}-Q_{H R S G}
$$

Thermal Efficiency of HRSG,

$$
\eta_{H R S G}=\frac{Q_{H R S G}}{\dot{Q}_{e g}}
$$

2.1.2. Determination of Net Power Output at Generator Terminal of Steam Turbine The actual power developed by the steam turbine $P_{S T}$ can be calculated from the relation:

Isentropic efficiency

$$
\eta_{S T_{i s}}=\frac{P_{S T}(\text { actual })}{P_{S T}(\text { isentropic })}=\frac{\dot{m}_{s}\left(h_{1}-h_{2^{1}}\right)}{\dot{m}_{s}\left(h_{1}-h_{2}\right)}
$$

\section{Steam turbine net power output}

$$
P_{N E T}=P_{S T}(\text { actual })-P_{p}
$$

where

$$
P_{p}=\text { pump power input }(\text { actual })=\dot{m}_{s}\left(h_{4^{1}}-h_{3}\right)
$$

The steam turbine cycle efficiency 


$$
\eta_{S T}=\frac{P_{N E T}}{Q_{H R S G}}
$$

The capacity of a steam plant is often expressed in terms of steam rate or specific steam consumption (S.S.C). Nag defined it as the rate of steam flow kg/s required to produce unit shaft output (1 kW) [19]

Specific Steam Consumption (SSC)

$$
\text { S.S.C }=1 / W_{\text {net }}(\mathrm{kg} / \mathrm{kW} \cdot \mathrm{h})
$$

Where $W_{\text {net }}=$ specific network output

Specific steam turbine work

$$
W_{S T}=\frac{P_{S T}(\text { actual })}{\dot{m}_{s}}
$$

Specific Pump Work

$$
W_{p}=\frac{P_{p}}{\dot{m}_{s}}
$$

$\therefore$ Net specific work

$$
W_{N E T}=W_{S T}-W_{P}
$$

The condenser cooling water system heat transfer (heat rejected to the condenser) gives

$$
Q_{2}=\dot{m}_{s}\left(h_{2}-h_{3}\right)
$$

Applying the energy balance equation between the condenser and the cooling water;

$$
\dot{m}_{w}=c_{p_{w}}\left(t_{\text {out }}-t_{\text {in }}\right)=\dot{m}_{s}\left(h_{2}-h_{3}\right)
$$

The condenser Efficiency $\eta, \eta_{\text {cond }}=\frac{\text { Actual temp.rise of cooling water }}{\text { maximum temp.rise of cooling water }}$

$$
\eta_{\text {cond }}=\frac{t_{\text {out }}-t_{\text {in }}}{T_{2}-t_{\text {in }}}
$$

Where; $\dot{m}_{s}$

$\dot{m}_{s}=$ Mass flow rate of steam in $\mathrm{kg} / \mathrm{s}$

$\dot{m}_{w}=$ Mass flow rate of cooling water

$c_{p_{w}}=$ Specific heat of water

$t_{\text {in }}=$ Temperature of cooling water into condenser

$t_{\text {out }}=$ Temperature of cooling water out of the condenser

$T_{2}=$ Condenser saturated temperature

\subsubsection{Combined Gas and Steam}

The combined-cycle unit combines the Rankine (steam turbine) and Brayton (gas turbine) thermodynamic cycles using HRSG. The HRSG comprising the economizer, the evaporator, and the superheater, trapped the energy in the exhaust gases of the turbine to generate steam for the steam turbine to generate more power. The schematic diagrams are shown in Figure 2 and Figure 3.

From Figure 2:

Omoku Gas turbine Cycle $\equiv \mathrm{a} \rightarrow \mathrm{b} \rightarrow \mathrm{c} \rightarrow \mathrm{d} \rightarrow \mathrm{a}$

Steam Turbine Cycle $\equiv 1 \rightarrow 2 \rightarrow 3 \rightarrow 4 \rightarrow 1$

Process $4 \rightarrow 1$ is the heat transfer process from exhaust gas of gas turbine to the Heat Recovery Steam Generator of the Steam turbine part.

The combined-cycle overall efficiency and power output are given by:

$$
\eta_{C C}=\eta_{S T}+\eta_{g T}-\eta_{S T} \eta_{g T}
$$




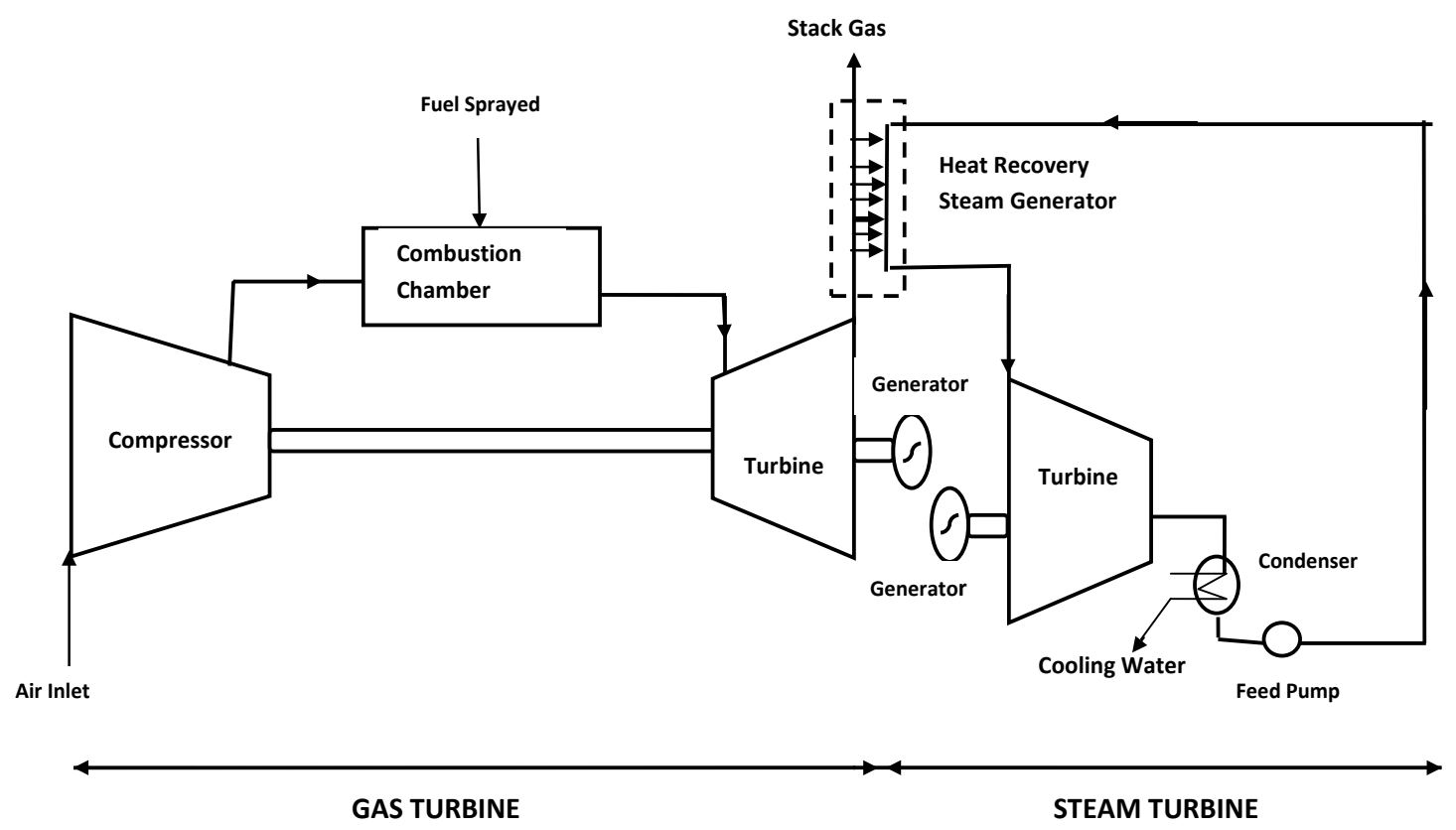

Figure 2. Schematic diagram of combined gas and steam cycle.

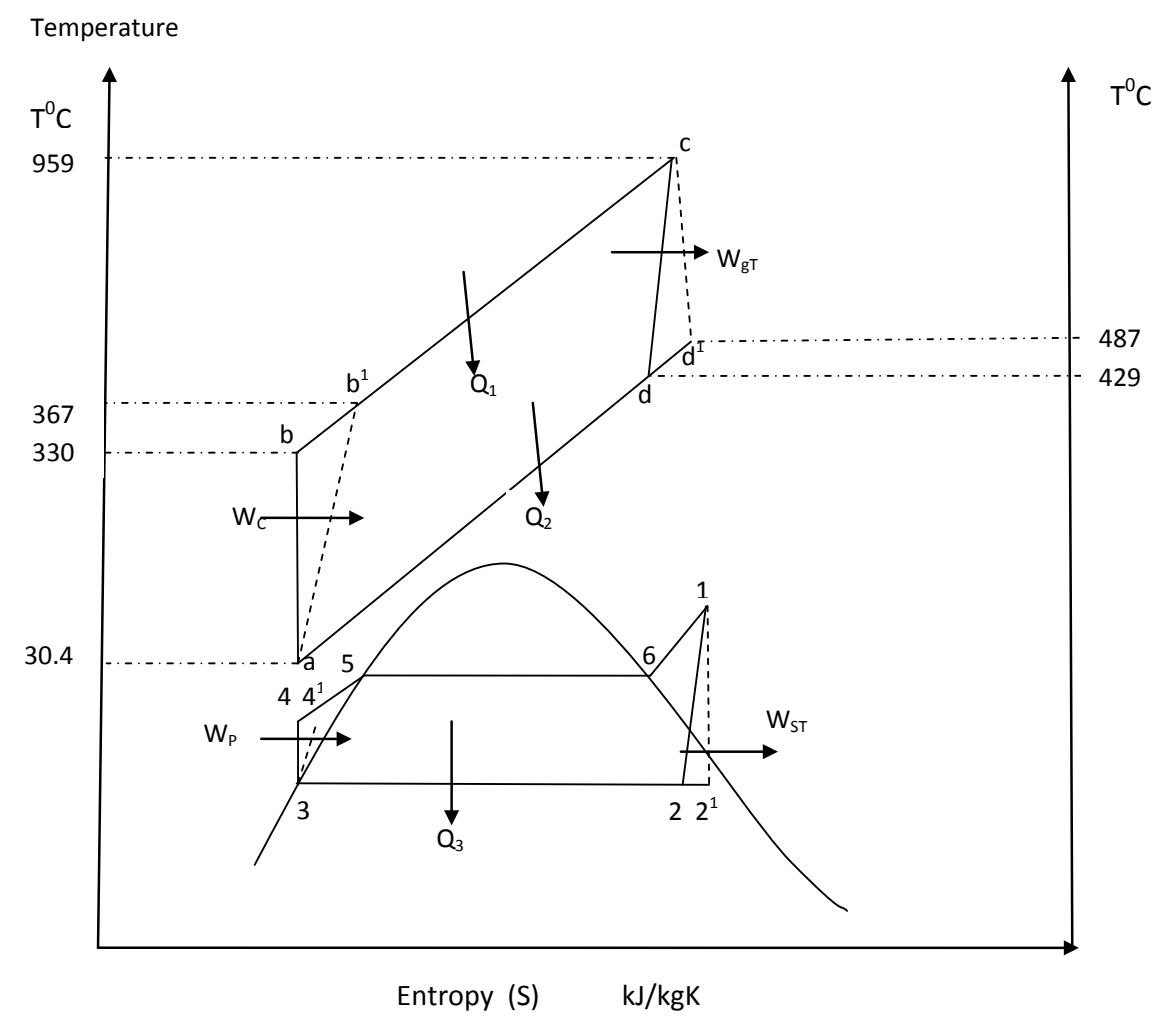

Figure 3. Combined gas and steam cycle power plant on T-S diagram.

$$
P_{C C}=P_{S T}+P_{g T}
$$

where $\eta_{C C}$ and $P_{C C}$ are combined cycle overall efficiency and power output respectively.

$P_{S T}=$ Steam turbine power output, $P_{g T}=$ gas turbine power output

$\eta_{S T}=$ Steam turbine thermal efficiency 
$\eta_{g T}=$ Gas turbine thermal efficiency

\subsection{HRSG and Steam Turbine Design Analysis}

Ragland et al. [13] in his study on combined cycle heat recovery optimization indicated that as a general guideline in the design of combined cycle power plant (CСPP), the gas turbine will represent $66 \%$ of the plant's electrical output assuming that the HRSG does not employ a duct burner. The remaining output will be supplied by the steam turbine.

This implies that for the Omoku gas turbine power plant having a capacity of $25 \mathrm{MW}$, the required output of the proposed combined cycle power plant will be $37.9 \mathrm{MW}$ (whose $66 \%$ gives the $25 \mathrm{MW}$ of the existing Omokugas turbine) and the remaining output will be supplied by the steam turbine which is $34 \%$ of the CCPP. Hence, the power output of the steam turbine that will match the existing Omoku gas turbine is $12.9 \mathrm{MW}$.

A single pressure HRSG without supplementary firing is employed in this design. A pinch point and approach temperature of $10^{\circ} \mathrm{C}$, and a condenser pressure of 0.1 bar were used in this work while the exhaust gas cooling temperature (HRSG stack temperature) was chosen above $160^{\circ} \mathrm{C}$ to avoid condensation of the exhaust gas at its acid dew point. For the purpose of this design, the inlet temperature difference between the condenser and the cooling water is taken as $16^{\circ} \mathrm{C}$ and the pinch point of $10^{\circ} \mathrm{C}$ is taken as the exit temperature difference resulting to a cooling water temperature rise of $6^{\circ} \mathrm{C}$ is chosen.

To arrive at the required steam turbine capacity of 12.9 MW resulting to a more efficient combined cycle system with increased output, MATLAB software was used to model the thermodynamics equations, and appropriate parameters of the various components of the steam turbine power plant were determined considering Nine (9) different conditions of iterating the steam saturation pressure from 20 bar to 50 bar and HRSG stack temperature within the range of $170^{\circ} \mathrm{C}$ to $190^{\circ} \mathrm{C}$, in applying the pinch technology for the HRSG and steam turbine analysis and the result is presented in Table 2.

\section{Results and Discussion}

\subsection{Results}

In order to determine the combined cycle components, all parameters were determined using the MATLAB model. The summary of the results obtained are shown in Table 2.

\subsection{Discussions}

Table 2 gives the result of the analysis after nine iterations. Iterations $1,3 \& 7$ show that as the saturation pressure increases from $20 \mathrm{bar}-40 \mathrm{bar}$ and HRSG stack temperature increases from $170^{\circ} \mathrm{C}-190^{\circ} \mathrm{C}$, the steam turbine net power output increases by $13.2 \%$ and the combined cycle overall efficiency increases by $6.2 \%$. This indicates that a simultaneous increase in steam saturation pressure and stack temperature improve the combined cycle power output and efficiency.

Iterations 2, 3 \& 6 show that as the stack temperature increases from $170^{\circ} \mathrm{C}$ to $190^{\circ} \mathrm{C}$ at constant saturation pressure of 30bar, the steam turbine net power output decreases from 13.5007 MW to 10.6399 MW and the combined cycle efficiency decreases from $48.4805 \%$ to $44.9933 \%$. This indicates that for every $20^{\circ} \mathrm{C}$ increase in the stack temperature, the turbine net power output and efficiency decreases by $21 \%$ and $7.2 \%$ respectively.

The $3^{\text {rd }}$ to $5^{\text {th }}$ iterations show that as the saturation steam pressure increases from 30 bar to 40 bar at constant HRSG stack temperature of $180^{\circ} \mathrm{C}$, the steam turbine net power output increases from $12.0690 \mathrm{MW}$ to 13.6630 MW and the combined cycle efficiency increase from $46.7923 \%$ to $49.4494 \%$. This show that for every 10 bar increase in the saturation steam pressure, there exist about $13.2 \%$ increase in the steam turbine net power output (which in turn increases the combined cycle power output) and 5.7\% increase in the combined cycle efficiency.

Iterations 6 - 9 show that at constant HRSG stack temperature of $190^{\circ} \mathrm{C}, \mathrm{P}_{\mathrm{CC}}$ increases as the saturation pressure increases. It indicates that for every $20^{\circ} \mathrm{C}$ increase in the saturation pressure, the $\mathrm{P}_{\mathrm{CC}}$ increases by $8 \%$. This behaviour is represented in Figure 4.

Figure 5 represents the variation of combined cycle efficiency with saturation pressure at different HRSG stack temperature. It shows a progressive increase in the combined cycle efficiency with increase in steam pressure and HRSG stack temperature to about $45 \mathrm{bar}, 190^{\circ} \mathrm{C}$. Further increase in the steam pressure at the stack temperature shows a decline in the overall cycle efficiency. It therefore indicate that for the modified design 


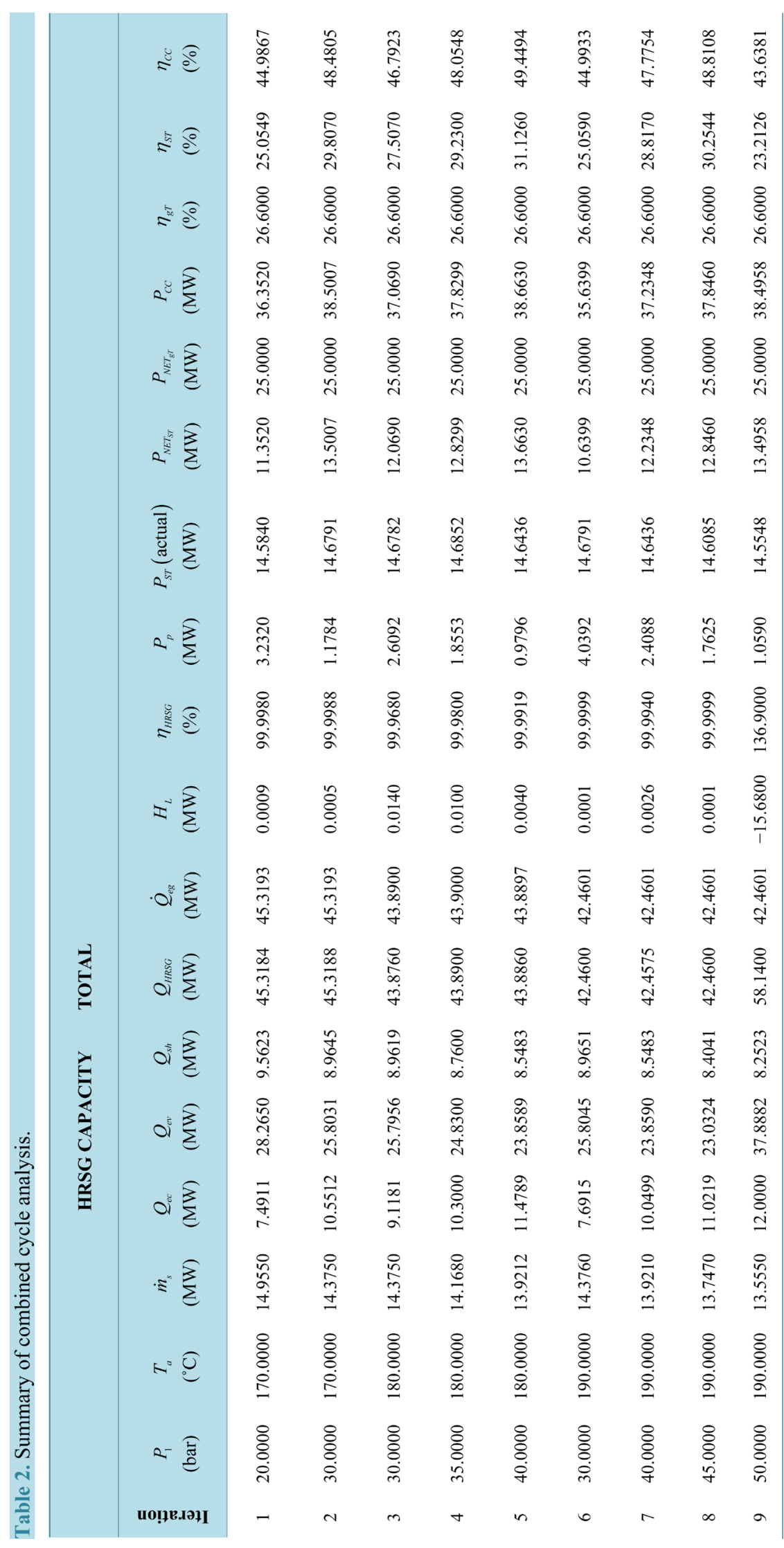




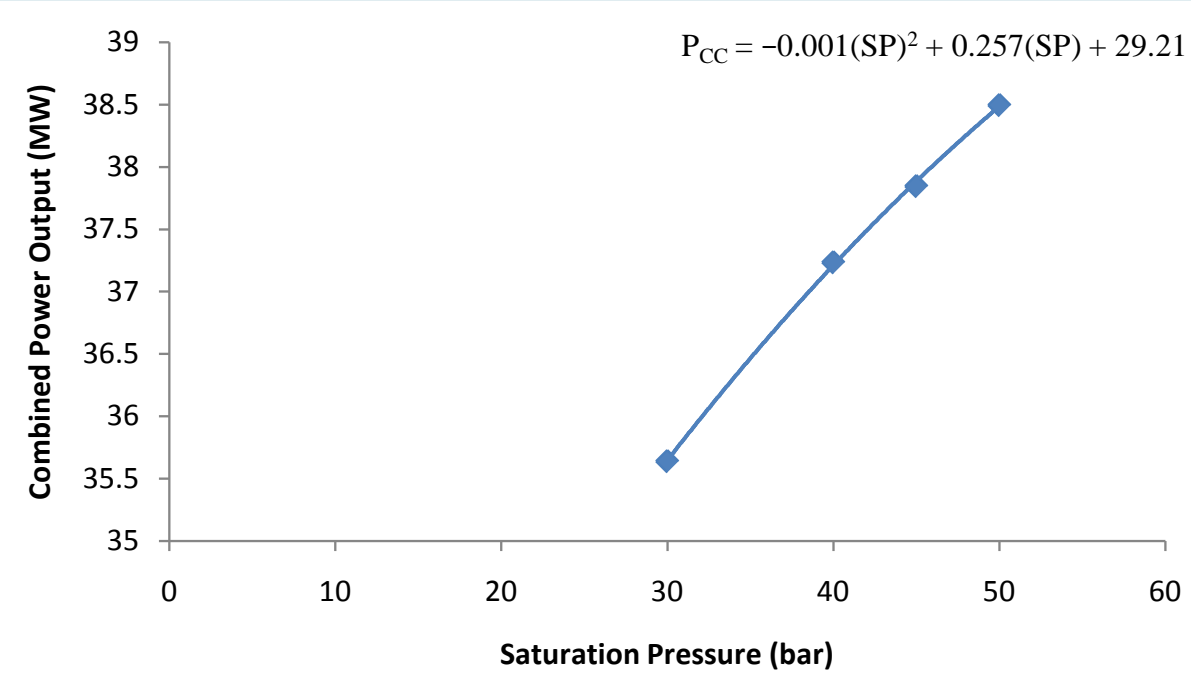

Figure 4. Variation of combined cycle power output with saturation pressure at constant HRSG stack temperature of $190^{\circ} \mathrm{C}$.

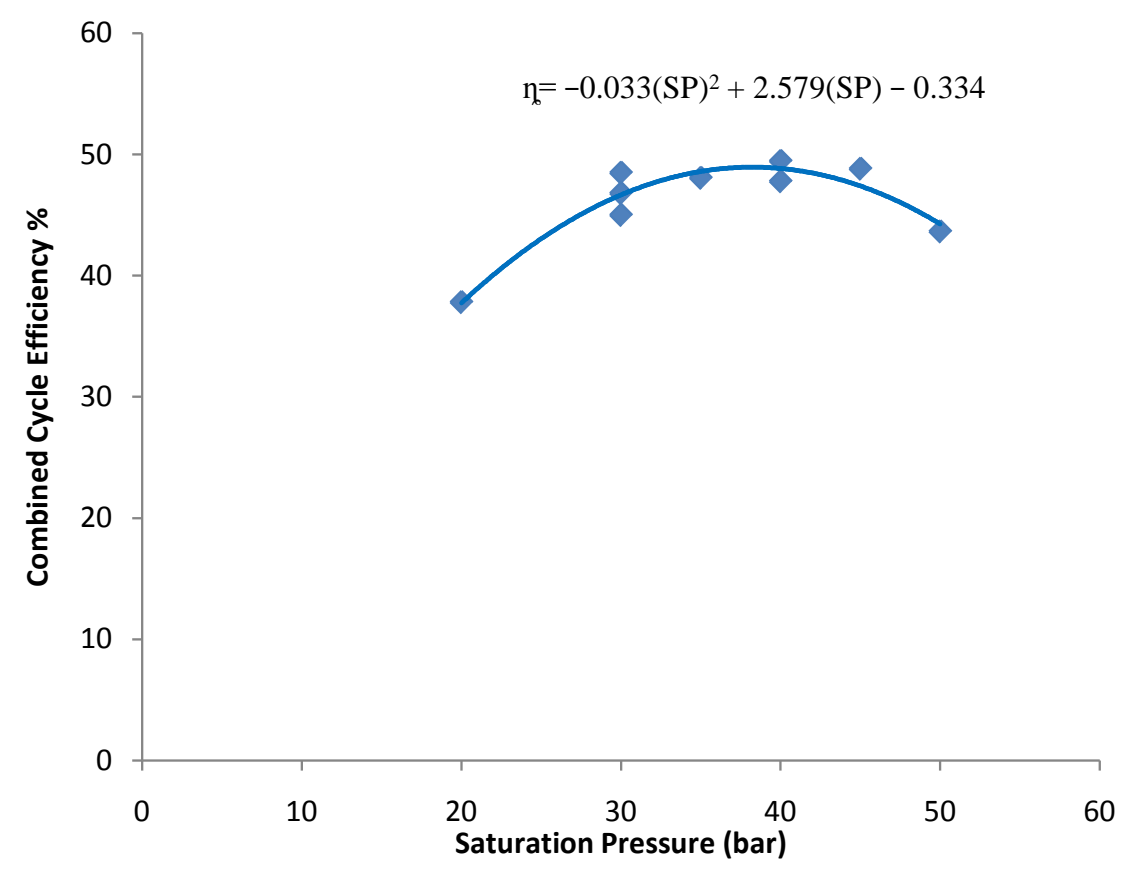

Figure 5. Variation of combined cycle efficiency with saturation pressure at different HRSG stack temperature.

process, a steam saturation pressure of 45 bar and HRSG stack temperature of $190^{\circ} \mathrm{C}$ is used as the maximum limiting condition.

Figure 6 shows the variation of steam turbine power output with saturation pressure at different HRSG stack temperature. It shows that the maximum steam power is generated at the saturation pressure of 35 bar and HRSG stack temperature of $180^{\circ} \mathrm{C}$.

Again, observation from iterations 2, $3 \& 6$ show that at constant saturation steam pressure and increased HRSG stack temperature from $170^{\circ} \mathrm{C}$ to $190^{\circ} \mathrm{C}$, the HRSG capacity decreases from $45.3188 \mathrm{MW}$ to 42.4575 MW as presented on Figure 7. This shows that for every $1^{\circ} \mathrm{C}$ increase in the stack temperature at a constant saturation pressure of 30 bar, the HRSG capacity decreases by $0.3 \%$. It is an indication that for higher HRSG capacity, the stack temperature should be within a considerable average value. This is represented in Figure 7.

As previously stated, a steam turbine capacity rating $12.9 \mathrm{MW}$ (34\% of the required CCPP) is required to 


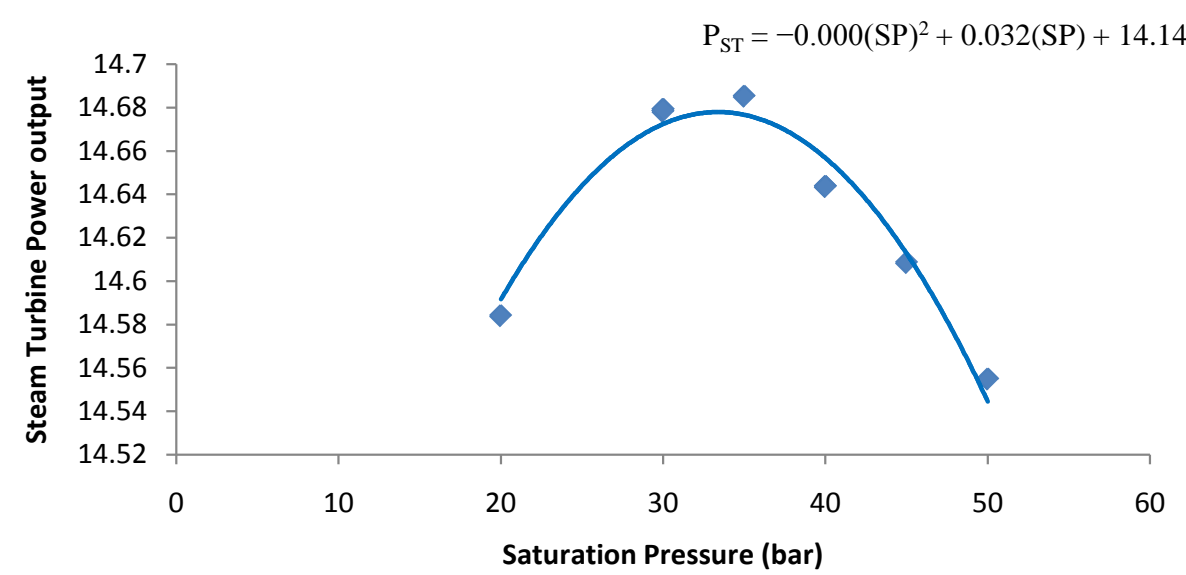

Figure 6. Variation of steam turbine power output with saturation pressure at different HRSG stack temperature.

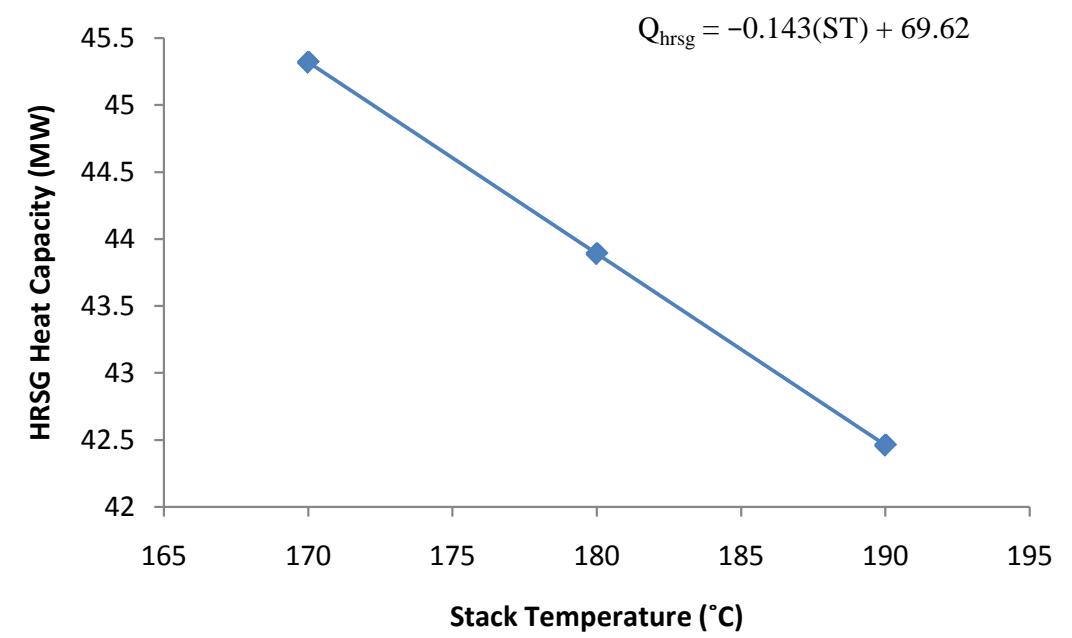

Figure 7. Variation of HRSG capacity with stack temperature.

Table 3. Steam cycle specification for combine cycle.

\section{HRSG}

STEAM TURBINE

- $\quad$ Stack temperature, $T_{a}=190{ }^{\circ} \mathrm{C}$

- Saturation temperature in Evaporator $T_{5}=257.1^{\circ} \mathrm{C}$

- Pinch point temperature difference $\Delta_{t_{p p}}=10^{\circ} \mathrm{C}$

- $\quad$ HRSG capacity $Q_{\text {HRSG }}=42.46{ }^{\circ} \mathrm{C}$

\section{Steam Turbine Generator}

- Poweroutput $P_{S T_{g e n}}=P_{N E T}=12.85 \mathrm{MW} \approx 12.9 \mathrm{MW}$

- Thermal efficiency $\eta_{g e n}=30 \%$

Condenser Cooling Water Parameters

- Inlet temperature $t_{\text {in }}=29.8^{\circ} \mathrm{C}$

- Outlet temperature $t_{\text {out }}=35.8{ }^{\circ} \mathrm{C}$

- Mass flow rate $\dot{m}_{w}=1180.42 \mathrm{~kg} / \mathrm{s}$

- Condenser efficiency $\eta_{\text {cond }}=37.50 \%$
- Inlet temperature $T_{1}=467{ }^{\circ} \mathrm{C}$

- Steam saturation pressure $P_{1}=45 \mathrm{bar}$

- Isentropic efficiency $\eta_{\text {is }}=89.06 \%$

- $\quad$ Thermal efficiency $\eta_{t h}=30.25 \%$

- Poweroutput $P_{S T}$ (actual) $=14.61 \mathrm{MW}$

- Mass flow rate $\dot{m}_{s}=13.747 \mathrm{~kg} / \mathrm{s}$

- Specific steam consumption S.S.C $=3.85 \mathrm{~kg} / \mathrm{kW} \cdot \mathrm{h}$

- Steam outlet pressure (condenser pressure) $P_{2}=0.1 \mathrm{bar}$

- Condenser capacity $\dot{Q}_{3}=29.61 \mathrm{MW}$

- $\quad$ Feed pump capacity $P_{p}=1.76 \mathrm{MW}$

\section{Combined Cycle Analysis}

- Overall power output $P_{C C}=37.9 \mathrm{MW}$

- Overall efficiency $\eta_{C C}=48.81 \%$ 
match the existing Omoku gas turbine of $25 \mathrm{MW}$ (66\% of the required CCPP), making it a combined cycle power plant (CCPP) of 37.9 MW capacity.

Table 3 shows the detailed specification of the required 12.9 MW capacity steam turbine (attained from the $8^{\text {th }}$ iteration of Table 2) for the combined cycle power plant. The steam turbine thermal efficiency is determined to be $30.25 \%$, with HRSG capacity of 42.46 MW which is equivalent to the heat rejected by the exhaust gas except for a loss of $0.0001 \mathrm{MW}$. It also shows the condenser and feed pump capacities to be $29.61 \mathrm{MW}$ and 1.76 MW respectively, and specific steam consumption (S.S.C) of $3.85 \mathrm{~kg} / \mathrm{kWh}$, indicating that a steam rate of 0.064 $\mathrm{kg} / \mathrm{s}$ is required for every $1 \mathrm{~kW}$ of shaft output. Again, results presented in Table 3 show that for the steam turbine capacity of $12.9 \mathrm{MW}$, to enhance condensation process, the cooling water enters the condenser at $29.8^{\circ} \mathrm{C}$ and leaves at $35.8^{\circ} \mathrm{C}$, indicating an actual cooling water temperature rise of $6^{\circ} \mathrm{C}$ and a maximum cooling water temperature rise of $16^{\circ} \mathrm{C}$ resulting to a condenser efficiency of $37.5 \%$. The cooling water flowing at 1180.42 $\mathrm{kg} / \mathrm{s}$ with the steam mass flow of $13.75 \mathrm{~kg} / \mathrm{s}$ indicates that for every $\mathrm{kg}$ of steam condensed, $85.55 \mathrm{~kg}$ of cooling water is required. Thus, to meet the huge demand of water, the power plant should be located where there is surplus water supply.

Deductions from all the analysis and discussions result to a combined cycle power output of 37.9 MW and an overall efficiency of $48.8 \%$. This higher efficiency of the combined cycle achieved compared with that of the dry mode Omoku gas turbine indicates that the amount of emissions discharged into the atmosphere per unit mass of fuel burnt is less.

\section{Conclusions}

The Omoku gas turbine power plant design has been improved from a simple cycle operating on a dry mode to a combined cycle operation by retrofitting a steam bottoming plant through the incorporation of a HRSG.

This produces additional electric power of $12.9 \mathrm{MW}$ (an increase of about 51\%) from steam power plant to the existing $25 \mathrm{MW}$ of the present gas turbine power plant, making a total power output of 37.9 MW for the combined cycle power plant; the steam turbine plant having a HRSG, condenser and feed pump capacities of 42.46 MW, 29.61 MW and 1.76 MW respectively. The condenser cooling water parameters include a mass flow of $1180.42 \mathrm{~kg} / \mathrm{s}$, inlet and outlet temperatures of $29.8^{\circ} \mathrm{C}$ and $35.8^{\circ} \mathrm{C}$ respectively with a condenser efficiency of $37.5 \%$. Moreover, the conversion increases the efficiency of the Omoku gas turbine power plant from $26.60 \%$ to $48.81 \%$ of the combined cycle power plant.

Based on the above parameters, SIEMENS steam turbine product of MODEL: SST-150 was recommended as the steam bottoming plant.

It is thus discovered that a heat flow of about $42.46 \mathrm{MW}$ which was otherwise being wasted in the EGT of the dry mode engine of the Omoku gas turbine could be converted to $12.9 \mathrm{MW}$ of electric power thus, reducing the total emission to the environment. In effect, the plant performance is enhanced.

\section{References}

[1] Rao, S. and Parulekar, B.B. (2007) Energy Technology: Non-Conventional, Renewable and Conventional. Khanna Publishers, Naisarak, Delhi.

[2] Mohamed, K.M. (2005) Parametric Analysis of Advanced Combined Power Generation Systems. M.Sc. Thesis, University of New Brunswick.

[3] German Advisory Council on Global Change (WBGU) (2011) World in Transition-Towards Sustainable Energy Systems. http://www.wbgu.de

[4] Goswami, D.Y. and Kreith, F. (2008) Energy Conversion. CRC Press, Taylor \& Francis Group, Boca Ranton, London, New York.

[5] Yadav, R. (2009) Steam and Gas Turbine and Power Plant Engineering. Central Publishing House, Allahabad.

[6] Anheden, M. (2000) Analysis of Gas Turbine System for Sustainable Energy Conversion. Ph.D. Thesis, Royal Institute of Technology, Stockholm.

[7] Nkoi, B., Pericles, P. and Theorklis, N. (2013) Performance Assessment of Simple and Modified Cycle Turboshaft Gas Turbine. Propulsion and Power Research, 2, 96-106. http://dx.doi.org/10.1016/j.jppr.2013.04.009

[8] Espanni, R., Ebrahimi, S.H. and Ziaeimoghadam, H.R. (2013) Efficiency Improvement Methods of Gas Turbine. Energy and Environmental Engineering, 1, 36-54.

[9] Ahmed, S.Y. (2013) Performance of the Combined Gas Turbine-Steam Cycle for Power Generation. Mathematical 
Theory and Modeling, 3, 12.

[10] Korobitsyn, M.A. (1998) New and Advanced Energy Conversion Technologies. Analysis of Cogeneration, Combined and Integrated Cycles. Febodruk BV.

[11] Lebele-Alawa, B.T., Hart, H.I., Ogagi, S.O.T. and Probert, S.D. (2008) Rotor-Blades’ Profile Influence on a Gas Turbine Compressor Effectiveness. Applied Energy, 85, 494-505. http://dx.doi.org/10.1016/j.apenergy.2007.12.001

[12] Lebele-Alawa, B.T. and Jo-Appah, V. (2015) Thermodynamic Performance Analysis of a Gas Turbine in an Equatorial Rain Forest Environment. Journal of Power and Energy Engineering, 3, 11-23. http://dx.doi.org/10.4236/jpee.2015.31002

[13] Ragland, A. and Stenzel, W. (2000) Combined Cycle Heat Recovery Optimization. Proceedings of 2000 International Joint Power Generation Conference, Miami Beach, 23-26 July 2000, 1781-1787.

[14] Armando, A. (2013) Optimization of Maputo Power Plant. Master of Science Thesis KTH School of Industrial Engineering and Management Energy Technology, STOCKHOLM.

[15] Jehar and Associates. Introduction to HRSG design. www.hrsgdesign.com

[16] Kehlhoffer, R. (1997) Combined Cycle Gas and Steam Turbine Power Plants. Penn Well Publishing Company, Oklahoma.

[17] Aref, P. (2012) Development of Framework for Thermo-Economic Optimization of Simple and Combined Gas Turbine Cycles. Ph.D. Thesis, School of Engineering, Cranfield University, Bedfordshire.

[18] Service Manual (Gas Turbine MS 5001) of 25 MW Unit of Omoku Power Generation Station. GEPS Oil \& Gas, Nuovo Pignone, Volume 1; G.T Description, Instruction \& Operation.

[19] Nag, P.K. (2011) Power Plant Engineering. 3rd Edition, Tata McGraw-Hill Education Private Limited, New Delhi.

\section{Nomenclature}

$c_{\text {peg }} \quad$ Specific heat of exhaust gas at constant pressure, $\mathrm{kJ} / \mathrm{kg} \cdot \mathrm{K}$

$c_{p_{w}} \quad$ Specific heat of water, $\mathrm{kJ} / \mathrm{kg} \cdot \mathrm{K}$

$h_{1} \quad$ Enthalpy at steam turbine inlet, $\mathrm{kJ} / \mathrm{kg}$

$h_{2} \quad$ Enthalpy at steam turbine outlet, $\mathrm{kJ} / \mathrm{kg}$

$h_{2^{1}} \quad$ Enthalpy at steam turbine outlet (actual), $\mathrm{kJ} / \mathrm{kg}$

$h_{3}^{2^{1}} \quad$ Enthalpy at condenser outlet, $\mathrm{kJ} / \mathrm{kg}$

$h_{4} \quad$ Feed water enthalpy, $\mathrm{kJ} / \mathrm{kg}$

$h_{4^{1}} \quad$ Feed water enthalpy (actual), $\mathrm{kJ} / \mathrm{kg}$

$h_{5}^{4} \quad$ Enthalpy at economizer exit, $\mathrm{kJ} / \mathrm{kg}$

$h_{6} \quad$ Enthalpy at evaporator exit, $\mathrm{kJ} / \mathrm{kg}$

$H_{L} \quad$ Heat loss, MW

$\dot{m}_{e g} \quad$ Mass flaw rate of exhaust gas in, kg/s

$\dot{m}_{w} \quad$ Mass flow rate of cooling water, $\mathrm{kg} / \mathrm{s}$

$\dot{m}_{s} \quad$ Mass flow rate of steam in, $\mathrm{kg} / \mathrm{s}$

$P_{1} \quad$ Steam saturation pressure, bar

$P_{2} \quad$ Condenser pressure, bar

$P_{C} \quad$ Compressor Power, MW

$P_{T} \quad$ Turbine Power, MW

$P_{C C} \quad$ Combined cycle power output, MW

$P_{g T} \quad$ Gas turbine power output, MW

$P_{N E T} \quad$ Steam turbine net power output, MW

$P_{P} \quad$ Pump power input (actual), MW

$P_{S T} \quad$ Steam turbine power output, MW

$\dot{Q}_{1} \quad$ Heat Supplied, MW

$\dot{Q}_{2} \quad$ Heat Rejected, MW

$\dot{Q}_{e c} \quad$ Heat recovered by economizer (economizer capacity), MW 
$\dot{Q}_{e g} \quad$ Heat rejected by exhaust gas, MW

$Q_{e_{e c}} \quad$ Exhaust gas energy at the economizer, $\mathrm{kJ} / \mathrm{kg}$

$Q_{e_{g_{e v}}} \quad$ Exhaust gas energy at the evaporator, $\mathrm{kJ} / \mathrm{kg}$

$Q_{e_{\text {eg }}} \quad$ Exhaust gas energy at the superheater, $\mathrm{kJ} / \mathrm{kg}$

$Q_{\text {HRSG }}$ Heat recovered by HRSG (HRSG capacity), MW

$Q_{s h} \quad$ Heat recovered by superheater (superheater capacity), MW

$Q_{e v} \quad$ Heat recovered by evaporator (evaporator capacity), MW

$T_{a} \quad$ HRSG stack Temperature, ${ }^{\circ} \mathrm{C}$

$T_{d} \quad$ Gas turbine exhaust Temperature, ${ }^{\circ} \mathrm{C}$

$T_{2} \quad$ Condenser saturated temperature, ${ }^{\circ} \mathrm{C}$

$T_{x} \quad$ Temperature of exhaust gas at pinch point, ${ }^{\circ} \mathrm{C}$

$t_{\text {in }} \quad$ Temperature of cooling water into condenser, ${ }^{\circ} \mathrm{C}$

$t_{\text {out }} \quad$ Temperature of cooling water out of the condenser, ${ }^{\circ} \mathrm{C}$

$W_{\text {net }} \quad$ Net work output, $\mathrm{kJ} / \mathrm{kg}$

\section{Greek Symbols}

$\eta \quad$ Efficiency, \%

$\eta_{\text {th }} \quad$ Thermal efficiency \%

$\eta_{c} \quad$ Compressor isentropic efficiency, \%

$\eta_{S T} \quad$ Steam turbine thermal efficiency \%

$\eta_{g T} \quad$ Gas turbine thermal efficiency \%

$\eta_{C C} \quad$ Combined cycle overall efficiency, \%

$\eta_{\text {cond }} \quad$ Condenser efficiency, $\%$

$\Delta_{t_{p p}} \quad$ Pinch point temperature difference, ${ }^{\circ} \mathrm{C}$

\section{Subscripts}

$\begin{array}{ll}\text { G } & \text { Gas } \\ \text { P } & \text { At constant pressure } \\ \text { th } & \text { Thermal } \\ \text { is } & \text { Isentropic } \\ \text { in } & \text { Inlet } \\ \text { out } & \text { Outlet }\end{array}$

\section{Abbreviations}

CCPP Combined cycle power plant

$\mathrm{CO}_{2}$ Carbondioxide

EGT Exhaust gas temperature

GE General electric

GT Gasturbine

HMI Human machine interface

HRSG Heat recovery steam generator

ICR Intercooled/recuperated

kg Kilo gram

$\mathrm{kW}$ Kilo watts

LPC Low pressure compressor

MW Mega watts

OPR Overall pressure ratio

SST Siemens steam turbine

ST Steam turbine

WBGU German advisory council on global change 